\title{
A review on the calculation of return on investment
}

\author{
E. Chuke Nwude*
}

Department of Banking and Finance, Faculty of Business Administration, University of Nigeria Nsukka, Nsukka 410001, Nigeria

\section{ARTICLE INFO}

\section{Article history:}

Received 15 June 2016

Received in revised form

10 September 2016

Accepted 30 September 2016

\section{Keywords:}

Return on investment

Capital employed

Earnings

Shareholders' funds

Dividend yields

Capital gains yield

\begin{abstract}
A B S T R A C T
This paper addresses the conceptual issues in the determination of the return on investment (ROI). It made use of archival research to find out the correct meaning of the term return on investment and its appropriate uses. The findings show that there are several ways to determine ROI. From equity perspective the two main measures of actual ROI are the net profit after interest and tax divide by shareholders' funds, and the sum of dividend yield (DY) and capital gains yield (CGY). From firm perspective six useable measures of ROI are EBITD/(GFA+GCA), EBIT/(NFA+GCA), $\mathrm{EBITD} /(\mathrm{GFA}+\mathrm{NCA}), \quad \mathrm{EBIT} /(\mathrm{NFA}+\mathrm{NCA}), \quad \mathrm{EBITAD} /(\mathrm{GFA}+\mathrm{GCA})$ and EBITAD/(GFA+NCA) as the need for each arises. The most frequent error committed and misconception in these computations is in the area of ascertainment of the appropriate denominator in terms of which period figures to use and whether it should be gross or net fixed asset and current asset. EBITAD/Total asset refers to ROI to the firm before amortization and depreciation while ROI to the firm after the amortization and depreciation can be EBIT/ (NFA+NCA) or EBIT/(NFA+GCA) based on choice of the investor but the latter is highly recommended. The ROI to the firm before the amortization and depreciation is EBITAD/(GFA+NCA) or EBITAD/(GFA+GCA) based on choice of the investor but the former is recommended. Measuring ROI based on wealth creation ratio is the division of the end-period value of the investment by the beginning-period value of the investment with benchmark that the ratio has to be greater than one. The mean historical ROI can be ascertained through the use of either arithmetic or geometric mean.
\end{abstract}

(C) 2016 The Authors. Published by IASE. This is an open access article under the CC BY-NC-ND license (http://creativecommons.org/licenses/by-nc-nd/4.0/).

\section{Introduction}

The primary concern of every investor is directed at the actual cash he would receive on his investment rather than the profit made by the company where he invested. It is of no importance to the investor if the company made huge profits but the investors received nothing in terms of return. That is why the actual cash he has received measures the soundness of his investment decisions. Entrepreneurs decide to start their own businesses in order to earn a good return on the money invested. Also investors decide to plunge their money into some already existing investments based on expectation of return on investment. If the return on investment and other profitability ratios

\footnotetext{
* Corresponding Author.

Email Address: chuke.nwude@unn.edu.ng (E. C. Nwude)

https://doi.org/10.21833/ijaas.2016.09.016

2313-626X/C) 2016 The Authors. Published by IASE

This is an open access article under the CC BY-NC-ND license

(http://creativecommons.org/licenses/by-nc-nd/4.0/)
}

demonstrate that this is not occurring then they should consider selling or restructuring the business and reinvesting elsewhere. For instance, for an investment to be worthwhile, the return on investment has to be greater than the cost of capital. Therefore in computing the return to investors that will be used to compare with the cost of capital, net receipt of benefits should be used against the total amount invested. Some standard financial management textbooks posit that the return on investment can be nominal, true or effective rate. It was claimed that the nominal rate of return is the rate by which amount invested on fixed income security is multiplied by the nominal interest rate attached to it. The true rate is the actual or current market rate of the security. Effective rate is the actual interest yield to maturity of the security. Some investors do not look at these three rates but see return simply as a measure of the monetary benefits obtained by an investor over a specified time period in return for a given amount of investment or amount of capital invested during the period. The urge among investors, especially the novices in the 
world of investment to ascertain the actual format for determining the rate of return on investment forms the background of this study.

ROI as a profitability ratio is used by bankers, investors, and business analysts to assess a company management's efficiency in applying available resources of the firm and its financial strength. It is a performance measure used to evaluate the efficiency of an investment or to compare the efficiency of a number of different investments. It is sometimes used to measure how well a company is managed. It is one of the most important ways of making judgements as to where to invest new investment funds as they become available. The concept ROI can be applied to a number of situations such as divisions, product lines, or product centres. For example, it can be applied to evaluation of a segment or a branch or department of an enterprise, a product line, a transaction or an individual investment, and even to evaluate the total enterprise. In this way, it gives management a basis for comparing the performance of different areas and shows how effectively each division used its invested capital to earn a profit.

ROI can also be used to evaluate a proposed investment in new equipment by dividing the increase in profit attributable to the new equipment by the increase in invested capital needed to acquire it. If the ROI so obtained is higher than the company's cost of capital prior to the investment, and no better investment opportunities exist for those funds, it may make sense to purchase the equipment. ROI is also very useful for equity investors. For example, a stockbroker might calculate the return of investing in a company by dividing dividends plus stock price change by the stock price paid. This calculation of ROI measures the gain (or loss) achievable by placing fund on an investment over a period of time.

For an investment to be worthwhile, the return on investment must be greater than the cost of capital. Recall that cost of capital is the expected rate of return that the market requires in order to attract funds to a particular investment. Cost of capital is the sum of the interest cost of debt capital used by a business and the amount of profit that the business should earn for its equity sources of capital to justify the use of the equity capital during the period. Interest is a contractual and definite amount for a period, whereas the profit that a business should earn on the equity capital employed during the period is not. Therefore, a business should set a definite goal of earning at least a certain minimum ROI and should compare its actual performance for the period against this goal.

The confusion here which constitutes the problem of the study is that there are many methods of measuring return on investment but the proper one to use at a particular time is still not quite clear to many investors. Therefore the main objective of this study is to address this confusion. With this in mind, we engaged archival research to find out the correct position of the term return on investment and its appropriate uses. The salient feature of the paper is to propose a treatment of this important topic in a non-technical way. The structure for the rest of paper is as follows. In section 2, the authors review some empirical studies and demonstrate the application of the techniques. Section3 explains the research methodology. Section 4 showcases the appropriate models and the various applications based on the outcome of the study. Section 5 presented the authors concluding remarks.

\section{Literature review}

From the perspective of Rees (1990), return on investment (ROI) is made up of capital gain or loss and the dividends or coupons received from the investment throughout the holding period. Ituwe (2006) defined ROI as a measure of the rate of productivity of assets in providing returns to both ordinary shareholders and long-term creditors. The higher the return the more efficient is the utilization of assets. Pandey (1999) refered to ROI as the ratio of earnings after interest and taxes to total capital employed. Achuchaogu (2002) defined ROI as the profitability of the firm measured in relation to the amount of investment. The term investment here may refer to total assets, capital employed or the owners' equity. Njoku and Jombo (2003) saw ROI as a measure of the company's percentage returns on its capital investment which consists of shareholders' funds and long term debts. They submit that the percentage return which represents financial returns must always be on the increase. Ihesiulo (2005) stated that ROI is a measure of the success of the firm in earning a net return on investment and it should be on the increase. Njoku (1997) posited that ROI is a measure of profitinvestment relationship in a firm. Investment here represents shareholders' funds and term liabilities while returns stands for earnings generated after payment of interest and taxes. Arnold and Hope (1990) stated that ROI is synonymous with accounting rate of return (ARR) which can be computed in many different ways. For example, ARR can be computed based on Annual net profit/Total investment, Annual net profit/Average book value of investment, all of which rely on traditional profit rather than on cash flow and does not consider time value of money. From Nwude (2004) ARR can be computed based on Total profit/Total investment, Total profit/Average book value of investment, Average Annual profit/Total investment, Average Annual profit/Average book value of investment, all of which rely on traditional profit rather than on cash flow and does not consider time value of money. Giles and Capel (1994) and Spivey (2000) stated that ROI is the average profit for a project expressed as a percentage of the capital outlay. These opinions are in consonance with the views of Bernstein and John (2000), Friedlob and Franklin (1996), Gill (1994), Hilton (1991), and Rees (1990).

Nwude (2004) suggested that return on investment should take care of the opportunity cost 
of capital invested, rate of inflation that affect the purchasing power of the money invested and the risk premium. He further states that the return on investment can be nominal, true or effective rate. Nominal rate of return is the rate by which amount invested on fixed income security (i.e. nominal face value) is multiplied by the nominal interest rate attached to it. The true rate is the actual or current market rate of the security. Effective rate is the actual interest yield to maturity of the security. Some investors do not look at these three rates but see return simply as a measure of the monetary benefits obtained by an investor over a specified time period in return for a given amount of investment or amount of capital invested during the period. From this point of view, he stressed that ROI is the amount of revenue received in a fiscal year in excess of every amount invested in the fiscal year in an activity expressed as a percentage of the amount so invested, while not recognizing time value of money concept. Damodaran (2001) said ROI is an accounting rate of return which measures the net income a firm's management is able to earn with its total assets, usually obtained by dividing the net profit after tax by total assets. Berk and DeMarzo (2009) and MacCormac and Teeling (1980) defined ROI as the ratio of net profit after tax to net asset. They state that this ratio by itself is of little value and that a better version is the return on owners' equity, which is the return the owners receive for investing their own funds. That is, the return on owners investment is equals to net profit after taxes divided by the owners net worth in the business. The Du Pont Formula, which is widely used, breaks down return on owners' investment into two parts namely net profit margin and asset turnover. With this, return on owners investment is equals to net profit margin multiplied by asset turnover.

Howells and Bain (2008) stated that financial asset which may take a number of forms receives return in the form of interest at discrete intervals, some with the possibility of capital gain, and discount rate and these expressed as a percentage of original purchase price is the return on such investment. They submit that the return on an asset is usually expressed as its average or mean return over a period of time. The return will consist of any income (interest or dividend) that the asset earns plus capital gain (or loss). Thus the return on an asset in period one is given by $K_{1}=\left[D_{1}+P_{1}-P_{0}\right] / P_{o}$ where $P_{o}$ is the price of the asset at the end of the previous period. The arithmetic mean return over $n$ periods is sum of the returns from period 1 to period $\mathrm{n}$ divide by Pandey (1999) agreed to this Howells and Bain (2008) position on return. They finally termed return as the cash flow generated by an asset usually expressed as a rate. Pandian (2005) stated return on asset (ROA) as measure of the overall efficiency of capital invested in business and expressed ROA as net income divide by total assets and ROE as net profit divide by net worth. The ROA will be same with ROE if the firm carries out all of its operations with owners' funds. But most times they differ because of financial leverage. When ROE is greater than ROA it shows that the firm has employed its borrowed funds efficiently to lever the rate of return to the advantage of shareholders. She reasons that as dividend is the regular income received by the shareholder, the shareholder would like to know the relationship between the market price and the dividend hence the need to compute dividend yield which is dividend per share (DPS) divide by market price per share (MPPS).

Chandra (2012) saw ROA as profit after tax divide by Average total assets but quickly points out ROA in formula is an odd measure because its numerator measures the return to shareholders whereas its denominator represents the contribution of all investors( equity and debt). He defines ROCE as EBIT (1-tax rate) divide by Average total assets. The EBIT (1-tax rate) is net operating profit after tax. He states that ROE also called return on net worth or return on shareholders' funds, which is a measure of interest to equity shareholders, is equity earnings divide by average equity. His reason for adopting average figures as denominator is not understood.

Arnold (2008) and Cuthbertson and Nitzsche (2005) saw ROCE as accounting rate of return (ARR) or return on investment (ROI) which they define as the ratio of the accounting profit to the investment in the project. The ratio can be calculated in a number of ways such as profit for the year/Asset book value at start of the year, average profit/initial capital invested, average annual profit/average capital invested but the most popular approach is to take profit after the deduction of depreciation. He points out that the amount of capital invested has to be considered alongside the income earned. He identified many variations in consideration of the amount of capital invested such as ROCE, ROI, ROE, and ARR, all measure return as a percentage of resources devoted. Brealey et al. (1995) computed ROA as (EBIT-tax)/Average total assets but point out that for comparative study of operating performance of firms, ROA equals to EBIT-(tax +interest tax shields)/Average total assets should be used even if the firms have radically different debt ratios. They dissected ROA into firm's asset turnover ratio and profit margin thus ROA = (Sales/Assets) $\mathrm{x}$ (EBITtaxes)/Sales. ROE is earnings available for common stock divided by average equity. Weston et al., (1996) calculate ROA as net income/total assets and ROE as net income available to common stockholders/common equity. Adopting preference stock as part of ownership Atrill (2006) expressed return on ordinary shareholders' funds (ROSF) as net profit after taxation and preference dividend (if any)/average ordinary share capital. He states that ROCE as a fundamental measure of business performance is net profit before interest and taxation divide by the sum of the averages of share capital, reserves and long-term loans. He regarded the long-term capital invested in the business as the sum of the averages of share capital, reserves and long-term loans. 
Ignoring debt financing, Ross et al. (1996) state that ROA is equals to ROE but since in the real world most firms have debt, ROA is usually not equal to ROE. Damodaran (2001) saw ROA as a measure of operating efficiency in generating profits from its assets. If ROA is measured prior to the effects of financing but post-tax, then ROA = EBIT(1-tax rate)/Total assets. If measured after removing the effects of financing but post-tax ROA $=[$ Net income +Interest expenses (1-tax rate)] / Total assets. He states that the later provides a cleaner measure of the true return on assets. Ignoring taxation and effects of debt financing ROA = EBIT $/$ Total assets Damodaran (2001) submited that ROCE = EBIT (1-t) divide by the sum of book value of debt and book value of equity. Banerjee (2009) saw ROI as average annual profit expressed as percentage of either cost of the project or its average cost. Setting aside the effects of taxes and debt financing, Fischer and Jordan (1995) stated that the productivity of total assets can be seen as ROA = EBIT/Assets which can be dissected into asset turnover and profit margin thus: $\mathrm{ROA}=$ (Sales/Assets) $\times$ (EBIT/Sales).

From the above review it can be seen that some of them make blanket statement on the meaning of ROI while not showcasing the make-ups of the numerator and the denominator of the ROI model. This is the gap the study strives to fill in order to guide especially the novice aright.

\section{Research methodology}

Archival research was engaged in this study in order to find the correct position of the term return on investment and its appropriate uses. Long-aged and contemporary textbooks, journals, bulletins and lecture notes were consulted to obtain what currently are the practice and the age-long conceptions on the return on investment. In each material consulted, efforts were made to gather all the views expressed by the author(s) on the issue of return on investment (ROI) and its variants. The researcher critically looked out for what exactly constitutes return on investment. Both local and foreign authors were consulted in order to obtain balanced information on the methods of measuring its various forms in the developed, developing and the emerging economies.

\section{Discussion of findings}

From the researchers conducted on return on investment we arrived at the following conceptions and definitions of return on investment as detailed below. It is a common belief in the literature that ROI should be obtained from the division of the net income by the total amount invested. Sure it is but what are the elements that constitute the net income and the total amount invested. This is a big question that begs for clarification. From accounting background net income connotes net profit (NP), earnings after interest and taxes (EAIT), profit after taxes (PAT) or profit after interest and taxes (PAIT).
All these nomenclatures mean and address one item of the same value and meaning. The primary name for all of them is net profit available to the residual owners of the firm, also called the common or ordinary shareholders. Therefore if one is out to determine the return on investment made by the ordinary shareholders equity in the firm, the right numerator and denominator should be division of the net profit by owners' equity stake usually called ordinary shareholders' funds or simply shareholders' funds. This is usually abbreviated to SHF. Based on this the ROI on owners' equity is the net profit available to ordinary shareholders divide by the amount of shareholders' funds usually referred to in financial statements as total equity. That is, the ROI to the owners' equity is EAIT/Total equity also called ROE.

Net income can also denote all incomes less operational expenses. Operational expenses are cash outflows directly connected to the main activities of the firm. They usually include costs of sales or goods sold, administrative expenses, selling and distribution expenses, and other incidental expenses. The make-up of each one of these expenditure headings is assumed to be known at this level. When the totality of these expenditures is removed from the total revenue, we have what we call operational profit. Other names for this operational profit include earnings before interest and taxes (EBIT) and profit before interest and taxes (PBIT). Remember that at this operational profit all the noncash items have been deducted either as included under administrative expenses or selling and distribution expenses. These non-cash items include depreciation and internally domiciled amortization. Therefore the balance left as operational profit is the earnings generated by the firm for the fund providers who are the debt-holders and equityholders. This is because the supposed share of the earnings for debtor-holders and taxes for the government has not been removed or accounted for. That is why operational profit is called earnings before interest and taxes (EBIT) or profit before interest and taxes (PBIT). Therefore whenever one is dividing EBIT by the total amount invested, what is being refers to is the ROI to both the debt-holders and the equity-holders and this is called ROI for the entire firm. Hence the model for this should be the division of the EBIT by the total amount invested by both the debt-holders and the equity-holders. That is, the ROI to the firm is EBIT/Total asset.

If the intention is to find out the ROI for the bond debt-holders the model should be interest earned by the bond holders divide by the total amount they staked in the bond facility. That is, the ROI to the bondholders is Interest to bondholders/Total amount of the debt. Likewise, for the preference shareholders the ROI model should be preference dividends earned by the preference shareholders divide by the total amount they staked in the preference stock. That is, the ROI to the preference shareholders is Preference dividends/Total amount of the preference stock. 
At times the numerator bears earnings before interest and taxes (EBIT) plus amortization and depreciation (EBITAD). The comparison of EBITAD with EBIT clearly shows a difference. Obviously in value-wise, EBITAD is greater than EBIT because the amortization and depreciation already deducted before arriving at EBIT are now added to get EBITAD. If one divides EBITAD by total asset, what is the person looking for? Since EBIT/Total asset refers to the ROI to the firm after the amortization and depreciation, then EBITAD/Total asset should refer to ROI to the firm before amortization and depreciation. The question here is which one of these two ratios is a better measure of return on investment to the entire firm? Looking at the constituents parts of the denominator can give a guide towards better resolution of this dilemma.

On the issue of what constitute the denominator of the ROI to equity-holders is settled but that of the ROI to the firm needs further clarification and polishing. Total asset can be expressed as gross or net. Gross total asset denotes value of the total asset without deduction of the value of the wear and tear in the usage of the assets in production of the goods and/or services called accumulated depreciation on the assets. Net total asset denotes value of the total asset with deduction of the value of the accumulated depreciation on the assets. The question now is at which stage should depreciation be deducted? What situation should call for either way? Remember that the value of the depreciation participated in generating the goods and/or services that produced the income for that year concerned. Therefore if we want to be equitable and fair we should recognize and add back the depreciation to EBIT in order to reflect the entire weight of the assets that were put to work in the year. Again since internally retained amortized funds were kept and utilized in the production process the weight should also be factored into the ROI assessment in order to show the full capacity of the firm to generate return on investment. However if these two items are deducted to obtain EBIT then the net total asset should be the appropriate denominator in the model. Similarly, if these two items are not deducted to obtain EBITAD then the gross total asset should be the appropriate denominator in the model. These scenarios again boil down to the question of which one is a better option?

Furthermore, total asset is made up of fixed asset plus current asset. Fixed asset can be gross or net depending on the position of depreciation. Likewise, current asset can be gross or net depending on the position of current liabilities. If we are talking of the return on permanent capital employed by the firm then current asset should be net. That is current asset less current liabilities to obtain net current asset (NCA). Fixed asset (FA) should also be net fixed asset (NFA) if we are looking for ROI to the firm after the amortization and depreciation, otherwise it should be gross fixed asset (GFA) if we are looking for ROI to the firm before amortization and depreciation. That is, ROI to the firm after the amortization and depreciation is EBIT/(NFA+NCA). The ROI to the firm before the amortization and depreciation is EBITAD/(GFA+NCA).

If we are talking of the return on total capital employed by the firm then current asset should be gross current asset (GCA) that is the totality of investments in current asset items. The fixed asset should be net fixed asset (NFA) if we are looking for ROI to the firm after the amortization and depreciation, otherwise it should be gross fixed asset (GFA) if we are looking for ROI to the firm before amortization and depreciation. That is, ROI to the firm after the amortization and depreciation is EBIT/(NFA+GCA). The ROI to the firm before the amortization and depreciation is EBITAD/(GFA+GCA).

From the analyses above one can depict that generally, ROI is the ratio of money gained or lost whether realized or unrealized on an investment relative to the amount of money invested. The general formula for computing ROI is income/invested capital. ROI can be computed on a company-wide basis by dividing earnings before interest, interest and taxes (EBIT) or earnings before interest, interest, taxes, amortization and depreciation (EBITAD) by the sum of gross or net fixed assets and current assets. This measure indicates how well the overall company is utilizing its investments. ROI can be computed on owners' basis by dividing earnings after interest, taxes, amortization and depreciation (EAITAD) by shareholders funds. This measure indicates how well the company is utilizing its investments in equity. Calculated in this way, ROI provides a good indicator of profitability that can be compared against competitors or an industry average. In a moderate inflationary economy, companies need at least an ROI higher than the level of inflation in order to fund future growth. If this ratio is too low, it can indicate poor management performance or a highly conservative business approach. On the other hand, a high ROI can either mean that management is doing a good job, or that the company is undercapitalized.

\subsection{Other concepts of return}

\subsubsection{Holding period return (HPR)}

The holding period return on an investment is the change in wealth between the time of purchase of the investment and the time when the investment is sold or liquidated. The change in wealth can be due to cash inflows in the form of interest or dividends or due to an increase or decrease in the price of the asset.

$\mathrm{HPR}=\frac{\text { Ending Value of Investment }}{\text { Beginning Value of Investmen }}=\frac{V_{n}}{V_{0}}=$
wealth creation ratio

where $V_{n}$ represents end of period value, $V_{0}$ represents beginning period value. 
When the value of $\mathrm{V}_{\mathrm{n}} / \mathrm{V}_{0}>1.0$ it reflects an increase in wealth, implying a positive rate of return during the holding period.

When the value of $V_{n} / V_{o}=1.0$ it reflects $a$ stagnant investment, implying no return during the holding period.

A value less than 1.0 means a decline in wealth or negative return during the period. A value of zero indicates a complete loss of the investment.

Since investors think of return in annual percentage terms the holding period return can be converted to an annual holding period yield thus:

Annual Holding Period Return $=$

$\frac{\text { Year-end value of investment }}{\text { Beginning year value of investment }} \rightarrow-1$

If $n$-period holding period return is given as HPR then annual holding period rate of return $=\mathrm{HPR}^{1 / \mathrm{n}_{-}} 1$ where $\mathrm{n}$ is the number of periods the investment is held. Remember that if the holding period is less than one year $n$ is always converted to a fraction of a year before being used. For example, if N250,000 is invested for 2 years for a return of N350,000. HPR $=\mathrm{N} 350,000 / \mathrm{N} 250,000=1.4$, Annual $\mathrm{HPR}=(1.4)^{1 / 2}-$ $1=0.183$. Another example is if $N 100,000$ was invested on $1^{\text {st }}$ January and becomes $N 112,000$ on $1^{\text {st }}$ July. HPR $=112000 / 100,000=1.12, A H P R=(1.12)^{1 / 2}$ $-1=(1.12)^{2}-1=1.255-1=0.2544$.

\subsubsection{Mean historical rates of return}

The rates of return from an investment held over a number of years will likely fluctuate from year to year resulting in different values for each year. Each of these returns is relevant in the analysis of investment returns. It is also necessary to have a summary figure to describe the investments typical rate of return or to serve as an indicator of the expected rate of return if one were to invest in the asset class. Two summary measures of return performance in this respect are the Arithmetic Mean (AM) and the Geometric mean (GM) rates of return.

a. Arithmetic mean (AM) = sum of the Annual Yields divided by the number of years (n). That is, $\mathrm{AM}=[\Sigma \mathrm{AHPR}] / \mathrm{n}$, where $\mathrm{AHPR}=$ respective Annual Holding period rate of return.

b. Geometric Mean $(\mathrm{GM})=\mathrm{n}^{\text {th }}$ root of the product of the Annual holding period return for $n$ years minus one. $\mathrm{GM}=\mathrm{P}^{1 / \mathrm{n}}-1$, where $\mathrm{P}=$ the product the annual holding period return as follows $\mathrm{P}=\left(\mathrm{HPR}_{1}\right)$ $\left(\mathrm{HPR}_{2}\right)\left(\mathrm{HPR}_{3}\right)$--- $\left(\mathrm{HPR}_{n}\right)$. For example, the AM and GM of the following data is obtained as shown in Table 1.

The GM is superior to AM because it indicates the compound annual rate of return based on the ending and beginning value of the investment. Hence it is a long- term measure of rate of return. From computation above if we compound the investment at the rate of $4.8 \%$ for 3years, we would get an ending wealth value of 1.1502. AM is for short term measure. To illustrate this claim, an example suffices. If the price of a security moves as shown in Table 2.
Table 1: Example of the AM and GM data

\begin{tabular}{|c|c|c|}
\hline \multirow{2}{*}{ Year } & Beginning value & Ending value \\
\cline { 2 - 3 } 1 & HPR & HPY \\
\hline \multirow{2}{*}{2} & 1000 & 1200 \\
\cline { 2 - 3 } & 1.20 & 0.20 \\
\cline { 2 - 3 } & 1200 & 1350 \\
\hline \multirow{2}{*}{3} & 1.125 & 0.125 \\
\cline { 2 - 3 } & 1350 & -0.148 \\
\hline \multicolumn{2}{|c|}{$\mathrm{AM}=(0.20+0.125+-0.148) / 3=0.059=5.9 \%$} \\
$\mathrm{GM}=[(1.20)(1.125)(0.852)]^{1 / 3}-1=0.048=4.8 \%$ \\
\hline
\end{tabular}

Table 2: Example suffices for short term measure (AM)

\begin{tabular}{|c|c|c|}
\hline \multirow{2}{*}{ Year } & Beginning value Ending value \\
\cline { 2 - 3 } 1 & HPR & HPY \\
\hline \multirow{2}{*}{2} & 200 & 400 \\
\cline { 2 - 3 } & 2.0 & 1.0 \\
\cline { 2 - 3 } & 400 & 200 \\
\hline \multicolumn{3}{|c|}{$\mathrm{AM}=(1.0+-0.5) / 2=0.25=25 \%$} \\
$\mathrm{GM}=(2.0)(0.5) 1 / 2-1=1.0-1=0=0 \%$ \\
\hline
\end{tabular}

The GM accurately reflect the true position of the investment as there was no change in the wealth position of the investor, yet the AM states the rate of return as $25 \%$. The $\mathrm{AM}$ is wrong in this sense. However, both AM and GM will be the same when rates of return are constant for all years. With varying rates of return over the years the GM will be lower than the AM. The geometric mean is the most appropriate measure of means when an average rate of change over a number of time periods is being calculated. It is a single measure of periodic growth rate which if repeated $\mathbf{n}$ times will transform the opening value into the terminal value. To measure the annual growth rate over $n$ years, the appropriate model for geometric mean is as follows: $\mathrm{GM}=$ $\left(1+g_{1}\right)\left(1+g_{2}\right)\left(1+g_{3}\right)---------(1+g n)^{1 / n}-1$, where $g$ is the periodic growth rates expressed as decimals.

\subsubsection{Required rate of return}

This is the minimum rate of return that compensates for the time value of money (time preference), the rate of inflation and the risk involved. The analysis and estimation of required rate of return is complicated by market behaviour over time. One of such is that we have a wide range of rates for alternative investments at any time. Two, rate of return on specific asset change dramatically over time. Three the difference between the rates available on different asset changes over time. Recall that investment takes place because of the possibility of earning a rate of return that will adequately compensate for the sacrifice of present consumption (price of waiting), the expected rate of inflation, and the uncertainly of the return. As a result the required rate of return is $R=R_{f}+R_{l}+R_{p}$, where $R_{f}=$ Risk free rate $=$ pure rate of interest $=$ price of time $=$ pure time value of money (i.e. time preference) = base interest rate in the absence of price level changes over time (inflation) and uncertainty about future cash flows $=$ price of waiting or deferring consumption till a later date. $\mathrm{R}_{\mathrm{I}}=$ Inflation rate $=$ 
compensation for loss in the value of money. $\mathrm{R}_{\mathrm{p}}=\mathrm{Risk}$ premium $=$ compensation for uncertainty associated with future payment. The required rate of return is a rate of return that compensates the investor for the time value of money during the period of investment, the expected rate of inflation during the period and the risk involved. This is the minimum rate of return one should accept from an investment to compensate one for deferring consumption. The required return on equity (RROE) which is also regarded as the cost of equity capital can be determined through the capital asset pricing model (CAPM) as enunciated by Sharpe (1964), Mossin (1965) and Lintner (1966). That is, $R R O E=R_{f}+\beta\left(R_{m}\right.$ $\left.-R_{f}\right)$, where $\beta\left(R_{m}-R_{f}\right)$ is the risk premium of equity stock concerned.

In determining the required return the following influencing factors should be considered. The determinants of risk-free rate $\left(\mathrm{R}_{\mathrm{f}}\right)$ consist of objective and subjective factors. The objective factor refers to the mood of the economy sets mood of available investment opportunities within the economy. The required rate of return on investment opportunities are determined in turn by the long-run real growth rate of the economy. The Subjective factor refers to the time preference of individuals for the consumption of income. The strength of the human desire for current consumption influences the rate of compensation required. The time preference varies among individuals and the market creates a composite rate that includes the preferences of all investors. The relative ease or tightropes in the capital market which depends on the supply and demand of capital, the increase or decrease in money supply through a change in monetary and fiscal policies constitute strong influencing factors in scheduling the risk-free rate in the economy.

Risk premium $\left(R_{p}\right)$ is the increase in the required rate of return over nominal risk free rate to compensate for any risk involved in the investment. Risk premium $\left(R_{p}\right)$ is a function of systematic and unsystematic risks. The major fundamental sources of these risks are as follows. Systematic risk is caused by market risk, purchasing power risk, interest rate risk, exchange rate risk, country risk etc. Unsystematic risk is caused by business risk, financial risk, and liquidity risk among others. For instance, business risk is the risk of income flow caused by the nature of the business, financial risk is the risk caused by methods of financing adopted by the business, liquidity risk is the risk introduced by the secondary market for an investment (the ease of buying and selling securities), exchange rate risk occurs where investment is in currency of another country, country risk is the risk due to changes in political, economic, social etc. of a country. Therefore risk premium $\left(R_{p}\right)$ is a function of risk-less rate (RR) market risk (MR), purchasing power risk (PPR), interest rate risk (IRR), exchange rate risk (ERR), country risk (CR), business risk, financial risk, and liquidity risk among other risks. That is, $R_{p}=f(R R+$ $\mathrm{MR}+\mathrm{PPR}+\mathrm{IRR}+\mathrm{ERR}+\mathrm{CR}+\mathrm{BR}+\mathrm{FR}+\mathrm{LR}+\mathrm{OR})$.

\subsubsection{Nominal risk free rate of return}

The nominal risk free rate of return is the rate expected from a riskless investment stated with respect to time value of money only. It remains the same and the factors that affect it include rate of inflation, condition at the capital market between surplus and deficit units of the economy, demand and supply of money etc. The nominal rates of return are adjusted for changes in general price levels by use of Fisher's model which states that, $1+$ Real Rate $=[1+$ Nominal Rate $] /[1+$ Inflation Rate $]$. The real rate of return $=(1+$ nominal rate $) /(1+$ Inflation Rate) -1 . Assuming that we have FGN treasury bills with normal return of $10 \%$ and rate of inflation of $5 \%$ the real rate of return is $[(1+0.1) /(1+0.05)]-1=$ 0.0476 , that is, $4.76 \%$.

\subsection{Implications of the findings}

The significance of this study rests on the usefulness of the findings as succinctly stated hereunder. Generally, ROI is the profit an investment generates expressed as a percentage of the value of the assets used to generate it. ROI includes all the income investor earns on the investment as well as any profit that results from selling the investment. It can be negative as well as positive. If the sale price plus any other income is lower than the purchase price we have negative ROI, otherwise we have positive ROI. Due to its versatility and simplicity ROI is a very popular metric or measure of how effectively and profitably the firm uses its capital to generate profit. It can be used as a comparative measure of the performance efficiency and profitability of a number of different investments. Investments with negative ROI should be rejected or restructured while those with positive ROI are preferred. It can be applied to a particular product or piece of equipment or to a business as a whole.

Therefore return on equity (ROE) is a version of ROI from the perspective of residual shareholders. It can equally be referred to as the return on capital employed by the ordinary shareholders. ROE is the net profit after interest and tax for a given period expressed as a percentage of the shareholders' investment in the business during the given period. Here we are looking at the rate of return on the amount invested by the ordinary shareholders in the business. Dividend yield (DY) is used to measure the rate of return that goes to equity investors based on dividend income. This dividend yield can be computed in two ways namely on gross and on net dividend. Gross dividend is the amount of dividend declared without deduction of tax attached to such payment while net dividend is the amount of dividend declared less the tax implication. When there is need to find out the rate of return that goes into the pockets of equity investors based on dividend income after tax, then net dividend yield is computed, otherwise gross dividend yield is needful. Net dividend yield is net dividend per share (NDPS) divide by net asset per share (NAPS) or current 
market price per share (CMPPS) while gross dividend yield is the gross dividend per share (GDPS) divided by net asset per share (NAPS) or current market price per share (CMPPS). When the net asset per share (NAPS) is used as the denominator it is called nominal dividend yield but when current market price per share (CMPPS) is used it is called current dividend yield. To measure the rate of return that goes to the coffer of equity holders per share in a firm based on earnings per share, earnings yield (EY) is usually computed. The earnings yield is the EPS divide by current net asset per share (NAPS) or current market price per share (CMPPS). When the net asset per share (NAPS) is used as the denominator it is called nominal earnings yield but when current market price per share (CMPPS) is used it is called current earnings yield. However the total return on investment per share of equity is ideally the sum of the dividend yield (DY) and the capital gains yield (CGY). The CGY is the change in price per share divide by the commencement price per share. That is $\mathrm{P}_{\mathrm{t}}-\mathrm{P}_{\mathrm{t}-1} / \mathrm{P}_{\mathrm{t}-1}$, where $P_{t}$ is the ending price per share while $P_{t-1}$ is the commencement or beginning price per share, all in terms of either net asset per share (NAPS) or market price per share (MPPS), but MPPS is mostly preferable. The MPPS is preferable because it is market determined and verifiable while NAPS can be doctored. Therefore the return on equity based on dividend income and capital gain or capital loss is stated thus: ROE = Dividend yield plus capital gain or minus capital loss. Symbolically presented, ROE = DY $+\mathrm{CGY}=\mathrm{D}_{\mathrm{t}} / \mathrm{P}_{\mathrm{t}-1}+\mathrm{P}_{\mathrm{t}}-\mathrm{P}_{\mathrm{t}-1} / \mathrm{P}_{\mathrm{t}-1}$. This model should be used to measure the rate of return on equity on dividend income and market price.

Return on capital employed (ROCE) is another version of ROI from the perspective of all the providers of capital used in running the entire business as a whole. It could be seen as the return on total asset (ROTA) employed by both the equity and debt. If we are thinking of total capital employed by the firm to generate the income then we should adopt gross current asset (GCA) and gross fixed asset to determine the ROA. With this in mind, ROCE = ROTA $=$ EBITD $/($ GFA+GCA $)$ or EBIT $/$ TA $=$ EBIT $/($ NFA + GCA). The first formula should be used when depreciation has not been deducted while the latter is used when depreciation has been deducted. When only the permanent capital employed is being considered the spontaneous financing such as the current liabilities should be discountenance here and only the permanent capital is recognized. Therefore the $\mathrm{ROCE}=\mathrm{ROPCE}=\mathrm{EBIT} /(\mathrm{NFA}+\mathrm{NCA})$ or EBITD/(GFA+NCA). The first formula should be used when depreciation has not been deducted while the latter is used when depreciation has been deducted. When the amortization item is involved both in the total or permanent capital employed the ROCE = ROTA $=$ EBITAD $/($ GFA+GCA $)$ and ROCE $=$ ROPCE $=$ $\mathrm{EBITAD} /(\mathrm{GFA}+\mathrm{NCA})$ respectively as the case may be.

\section{Conclusion}

The return on investment (ROI) can be determined from different perspectives. It could be from equity perspective or from firm perspective. From equity perspective the two major variants of measure of actual ROI with respect to equity are the net profit after interest and tax divide by shareholders' funds, and the sum of dividend yield (DY) and capital gains yield (CGY). Other measures used for various reasons include earnings yield, dividend yield, and capital gains yield. From firm perspective six useable models suffice. Looking at the ROCE it could be total assets or only permanent capital used to finance the assets is considered. With total asset employed ROI = ROTA before and after deduction of depreciation $=\mathrm{EBITD} /(\mathrm{GFA}+\mathrm{GCA})$ and $\mathrm{EBIT} / \mathrm{TA}=\mathrm{EBIT} /(\mathrm{NFA}+\mathrm{GCA})$ respectively. Adopting only the permanent capital as the capital employed ROI = ROPCE before and after deduction of depreciation $=$ EBITD $/($ GFA+NCA $)$ and EBIT $/$ TA $=$ $\mathrm{EBIT} /(\mathrm{NFA}+\mathrm{NCA})$ respectively. When the amortization item is involved both in the total or permanent capital employed the ROCE $=$ ROTA $=$ $\mathrm{EBITAD} /(\mathrm{GFA}+\mathrm{GCA})$ and $\mathrm{ROCE}=\mathrm{ROPCE}=$ EBITAD/(GFA+NCA) respectively

ROA (i.e. EBIT/total asset) reflects the earning power performance of a business. It is not affected by interest charges and tax burden. It denotes operating performance which is why ROA is eminently suited for inter-firm comparison. The numerator represents a measure of pre-tax earnings belonging to all sources of finance and the denominator represents total financing. ROCE is a post-tax version of ROA (i.e. EBIT (1-tax rate) / total asset). Note that in all these measures, the numerator reflects current values while the denominator reflects historical values. ROCE assesses the performance of a business as a whole after it has performed while ARR which has the same approach as ROCE but assesses the performance of a business as a whole before it has performed. That is ROCE is calculated post-performance while ARR is pre-performance with a target in mind.

In summary, return on asset (ROA) expressed as EBIT divided by total assets made of net fixed asset plus gross current asset $(\mathrm{NFA}+\mathrm{GCA})$ is the appropriate measure of the overall efficiency in the use of capital invested in business. This view is in line with the submissions of Damodaran (2001) and Fischer and Jordan (1995). If ROA is measured prior to the effects of financing but post-tax, then ROA = EBIT (1-tax rate) / Total assets. If measured after removing the effects of financing but post-tax ROA = [Net income +Interest expenses (1-tax rate)]/Total assets. He states that the later provides a cleaner measure of the true return on assets. Ignoring taxation and effects of debt financing ROA = EBIT/Total assets.

The division of the EBIT by the total amount invested by both the debt-holders and the equityholders yields the ROI to the entire firm (that is EBIT/Total asset). If the intention is to find out the ROI for the bond debt-holders the model should be interest earned by the bond holders divide by the 
total amount they staked in the bond facility. That is, the ROI to the bondholders is Interest to bondholders/Total amount of the debt. Likewise, for the preference shareholders the ROI model should be preference dividends earned by the preference shareholders divide by the total amount they staked in the preference stock. That is, the ROI to the preference shareholders is Preference dividends/Total amount of the preference stock.

The ROI to the owners' equity is EAIT/Total equity also called ROE. ROE expressed as net profit divided by owners' net worth or shareholders' funds is a good measure of the proportion of the firm's total net profit in the hands of the residual owners of the firm. Another variant of ROE when investment in shares is involved is the sum of dividend yields and capital gains (or loss) divided by the original value of amount invested.

Dividend yield (DY) as a measure of the rate of return that goes to equity investors based on dividend income can be computed on gross and on net dividend.

The return on capital employed (ROCE) =EBITD / $(\mathrm{GFA}+\mathrm{GCA})$ or EBIT $/ \mathrm{TA}=\mathrm{EBIT} /(\mathrm{NFA}+\mathrm{GCA})$. The first formula should be used when depreciation has not been deducted while the latter is used when depreciation has been deducted. When only the permanent capital employed is being considered the spontaneous financing such as the current liabilities should be discountenance here and only the permanent capital is recognized. Therefore the ROCE $=$ ROPCE $=$ EBIT / (NFA+NCA $)$ or EBITD / (GFA+NCA). The first formula should be used when depreciation has not been deducted while the latter is used when depreciation has been deducted. When the amortization item is involved both in the total or permanent capital employed the ROCE = EBITAD / (GFA+GCA) or EBITAD / (GFA+NCA) respectively as the case may be.

\section{References}

Achuchaogu KC (2002). Contemporary issues in financial management. Knowroch, Lagos, Nigeria.

Arnold G (2008). Corporate financial management. $4^{\text {th }}$ Edition, FT Prentice Hall, Pearson Education, London, UK.

Arnold J and Hope T (1990). Accounting for management decisions. Prentice-Hall, London, UK.

Atrill P (2006). Financial management for decision makes. $4^{\text {th }}$ Edition, FT Prentice Hall, Pearson Education, London, UK.

Banerjee B (2009). Fundamentals of financial management. Eastern Economy Edition, PHI Learning, New Delhi, India.

Berk J and DeMarzo P (2009). Corporate finance: The core. Pearson International edition, Pearson Prentice Hall, London, UK.
Bernstein LA and John JW (2000). Analysis of financial statements. McGraw-Hill, New York, USA.

Brealey RA, Myers SC, and Marcus AJ (1995). Fundamentals of corporate finance. McGraw-Hill, New York, USA.

Chandra P (2012). Investment analysis and portfolio management. CFM-Tata McGraw-Hill, New Delhi, India.

Cuthbertson K and Nitzsche D (2005). Investments spot and derivatives markets. John Wiley, Chicago, USA.

Damodaran A (2001). Corporate finance-theory and practice. John Wiley, Chicago, USA.

Fischer DE and Jordan RJ (1995). Security analysis and portfolio management. Eastern Economy Edition, PHI Learning Publisher, New Delhi, India.

Friedlob GT and Franklin JP (1996). Understanding return on investment. Wiley, Chicago, USA.

Giles RS and Capel JW (1994). Finance and accounting. Macmillan, London, UK.

Gill JO (1994). Financial basics of small business success. Crisp Publications, Menlo Park, Los Angeles, USA.

Hilton RW (1991), Managerial accounting. McGrawHill, New York, USA.

Howells P and Bain K (2008). The economics of money, banking and finance-a European text. FT Prentice Hall, London, UK.

Ihesiulo OS (2005). The principles of business finance. Barloz Publishers, Owerri, Nigeria.

Ituwe CE (2006). Strategic management: Theory and practice. Excel bookhouse, Lagos, Nigeria.

MacCormac MJ and Teeling JJ (1980). Financial management. Gill and Macmillan, Dublin, Ireland.

Njoku PNO (1997). A practical guide to bank lending and credit administration. Du Prince and Paul, Umuahia, Nigeria.

Njoku PNO and Jombo OC (2003). Fundamentals of business finance and financial management, Barloz Publishing, Owerri, Nigeria.

Nwude C (2004). Basic principles of financial management-a first course. Nwabude, Enugu, Nigeria.

Pandey IM (1999). Financial management. Vikas Publishing House, New Delhi, India.

Pandian P (2005). Security analysis and portfolio management. Vikas Publishing House, India.

Rees B (1990). Financial analysis. Prentice-Hall, London, UK.

Ross SA, Westerfield RW and Jaffe J (1996). Corporate Finance. McGraw-Hill, New York, USA. 
Sharpe WF (1964). Capital Asset Prices: A Theory of Market Equilibrium under Conditions of Risk. Journal of Finance, 19: 425-442.

Mossin J (1966). Equilibrium in a capital asset market. Econometrica, 34: 768-783.

Lintner J (1965). The Valuation of risky assets and the selection of risky investments in stock portfolios and capital budgets. Review of Economics and Statistics, 47: 13-37.

Spivey J (2000). Companies searching for everelusive internet ROI. Mississippi Business Journal, 12(1): 11-23.

Weston JF, Besley S and Brigham EF (1996). Essentials of managerial finance. The Dryden Press. 